\title{
SETTLING DOWN OF AZOSPIRILLUM BACTERIA IN ROOT ZONE OF SPRING WHEAT UNDER THE INFLUENCE OF SOIL FUNGUS CHAETOMIUM COCHLIODES 3250
}

\section{Kopilov E.P.}

Institute of Agriculture Microbiology UAAS

97, Shevchenko str., Chernihiv, 14027, Ukraine

E-mail: evhenykopilov@rambler.ru

Pure bacteria cultures of Azospirillum genus able to fix atmospheric nitrogen were isolated from rhizosphere soil, washed-off roots and histosphere of spring wheat plants. By their phenotype signs and the results of molecular-genetic analysis they were related to the Azospirillum brasilense species. It was shown that strain A. brasilense 104 actively colonizes rhizospheric soil, root surface and is able to penetrate in inner plant tissues during its introduction in root system of spring wheat. The soil ascomycete Chaetomium cochliodes 3250 promotes settling down of Azospirillum bacteria in root zone of spring wheat especially in plants hystosphere which results in increasing of chlorophyll $a$ and $b$ content in leaves.

Key words: Azospirillum brasilense, nitrogen-fixing bacteria, spring wheat, endophytes, chlorophyll, Chaetomium cochliodes 3250

Bacteria of Azospirillum genus are the one of the most investigated objects among plants rhizosphere. The manner of their influence on plants is multifaceted. This is a high $\mathrm{N}_{2}$-fixing activity and as a consequence proving of nitrogen plants nutrition, capability to produce biological active substances which activate chloroplast genesis, stimulate plants growth and development, rise up their resistant to unfavorable conditions of environment and deceases agents.

The aim of this work was studying of Chaetomium cochliodes Palliser 3250 peculiarities to be conductive to Azospirillum bacteria to penetrate into spring wheat roots.

Materials and methods. Calculation of Azospirillum bacteria we made on Caceras solid agar medium with red congo where they make dark red, little, dry, wrinkled colonies $0,5-1,5 \mathrm{~mm}$ in diameter [1].

Preliminary identification of selected bacteria was carried out by morphological, cultural, physiological and biochemical features accord- 
ing to Bergi key [8]. Besides we also used the description of bacteria from Azospirillum genus in original publications [4].

We used universal oligonucleotide primers which was conformed to conservative positions on 3-' and 5-' endings of 16S rRNA gene. $16 \mathrm{~S}$ Forward (CGG-CCC-AGA-CTC-CTA-CGG-GAG-GCA-GCA) and $16 \mathrm{~S}$ Revers (GCG-TGG-ACT-ACC-AGG-GTA-TCT-AAT-CC). The reaction of amplification was carried out on Applied Biosystems appliance. PCR-products were separated in 1,5\% agarose by horizontal electrophoresis. Detection of obtained PCR-products was made on Applied Biosystems ABI Prism 3130 automatic capillary analizer.

The ability of $C$. cochliodes 3250 to colonize spring wheat root system was investigated in laboratory experiment with sterile conditions [7]. Colouring of mold mycelium in root tissues made by Kobel method [6]. Micropreparations were investigated under microscope MC 200(T) ("Micros", Austria). Photos were made by color digital camera E 5400 ("Nikon", Korea).

The maintenance of chlorophylls $a$ and $b$ in leafs was investigated by spectrophotometer method [5].

Results and discussions. From rhizosphere soil, washed off roots and histosphere of spring wheat we picked out clean bacteria cultures of Azospirillum genus. There were selected the 11 most active strains able to fix atmospheric nitrogen. They were described by phenotypic features and investigated with molecular-genetic analysis methods. For the present day GenBank database contains information about 11 species of Azospirillum genus bacteria. As is well known from the literature sources all the Azospirillum strains selected from Ukrainian soils belong to A. brasilense and A. lipoferum. Therefore we carried through the phylogenetic analysis of picked up strains as well as typical strains of A. brasilense $\mathrm{Sp} 7$ and A. lipoferum 59b obtained from the Bacterial Collection of the Institute of Biochemistry and Physiology of Plants and Microorganisms RAS.

On the basic of cultural, morphological, physiological and biochemical signs the selected strains were considered to Azospirillum genus, $A$. brasilense species.

With the help of PCR-analysis the amplificants of 16S rRNA gene were obtained and sequenced. Electrophoresis of PCR-products in 1,5\% agarose is presented on the fig. 1 


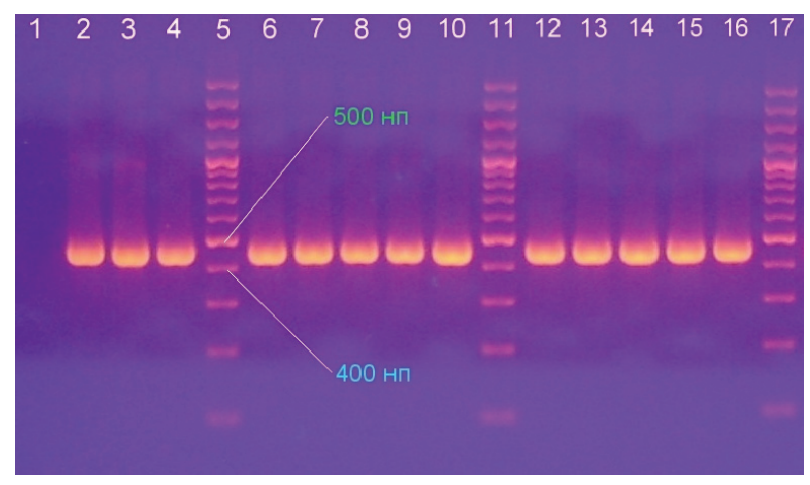

Fig. 1. Electrophoresis of PCR-products in 1,5\% agarose

The results of investigated strains identification obtained during comparative analysis of nucleotide sequences of the bacterial 16S rRNA genuse with similar sequences of A. brasilense and A. lipoferum from GenBank database are presented in the table 1.

The comparative analysis of sequencing results revealed $100 \%$ identity of $16 \mathrm{~S}$ rRNA of investigated bacteria with the similar sequences of $A$. brasilense GenBank database. Thus the identification of the selected strains with the help of sequence analysis of $16 \mathrm{~S}$ rRNA gene matches with the results obtained during investigation of phenotypic signs.

The selected Azospirillum strains were tested in series of vegetative experiments with spring wheat, where their ability to form associations with plants rising up $\mathrm{N}_{2}$-fixing activity in root zone, activating synthesis of photosynthetic pigments, proving plants growth and development have been studied. As a result we found out the most effective strain A. brasilense 104 .

One of the important conditions of the effective interaction of introduced associative bacteria strains with plants is the capability of microorganisms to colonize plants roots actively. For investigation of the ability of $A$. brasilense 104 to settle down in spring wheat root zone we obtained streptomycin stable mutant which didn't differ from primer strain by its cultural, morphological and physiological properties.

We investigated the dynamics of quantity of mutant cells introduced into root zone of spring wheat in rhizospheric soil, on the washed off roots and hystosphere of plants in vegetative experiment. The obtained results testify that Azospirillum cells are able to settle down not only in rhizosphere soil and root surface but they penetrate 
into inner tissues of spring wheat plants.

Table 1. The results of identification of investigated strains during comparative analysis of nucleotide sequences of 16S-RNA gene from Gen Bank database

\begin{tabular}{|c|c|c|c|}
\hline $\begin{array}{l}\text { Strain } \\
\text { number }\end{array}$ & Species and the number in Gen Bank & $\begin{array}{c}\text { Identity, } \\
\%\end{array}$ & $\begin{array}{l}\text { The number } \\
\text { of nucleoti- } \\
\text { des identical } \\
\text { to } 16 \mathrm{~S} \text { RNA } \\
\text { fragment }\end{array}$ \\
\hline 1 & 2 & 3 & 4 \\
\hline 145 & $\begin{array}{l}\text { Azospirillum brasilense DQ438999 } \\
\text { Azospirillum sp. 7C AF411852 }\end{array}$ & 100 & $392(r)$ \\
\hline 121 & $\begin{array}{l}\text { A. brasilense DQ438999 } \\
\text { Azospirillum sp. 7C AF411852 }\end{array}$ & 100 & $394(r)$ \\
\hline 114 & $\begin{array}{l}\text { A. brasilense DQ438999 } \\
\text { Azospirillum sp. 7C AF411852 }\end{array}$ & 100 & $395(r)$ \\
\hline 108 & $\begin{array}{l}\text { A. brasilense DQ438999 } \\
\text { Azospirillum sp. 7C AF411852 }\end{array}$ & 100 & $382(r)$ \\
\hline 93 & $\begin{array}{l}\text { A. brasilense DQ438999 } \\
\text { Azospirillum sp. 7C AF411852 }\end{array}$ & 100 & $373(r)$ \\
\hline 89 & $\begin{array}{l}\text { A. brasilense DQ438999 } \\
\text { Azospirillum sp. 7C AF411852 } \\
\text { A. brasilense AY324110 } \\
\text { A. brasilense (NCIMB 11860) Z29617 }\end{array}$ & 100 & $388(r)$ \\
\hline 102 & $\begin{array}{l}\text { A. brasilense DQ438999 } \\
\text { Azospirillum sp. 7C AF411852 } \\
\text { A. brasilense AY324110 } \\
\text { A. brasilense (NCIMB 11860) Z29617 }\end{array}$ & 100 & $389(r)$ \\
\hline 85 & $\begin{array}{l}\text { A. brasilense DQ438999 } \\
\text { Azospirillum sp. 7C AF411852 } \\
\text { A. brasilense AY324110 } \\
\text { A. brasilense (NCIMB 11860) Z29617 }\end{array}$ & 100 & $395(r)$ \\
\hline 83 & $\begin{array}{l}\text { A. brasilense DQ438999 } \\
\text { Azospirillum sp. 7C AF411852 } \\
\text { A. brasilense AY324110 } \\
\text { A. brasilense (NCIMB 11860) Z29617 }\end{array}$ & 100 & $395(r)$ \\
\hline 72 & $\begin{array}{l}\text { A. brasilense DQ438999 } \\
\text { Azospirillum sp. 7C AF411852 } \\
\text { A. brasilense AY324110 } \\
\text { A. brasilense (NCIMB 11860) Z29617 }\end{array}$ & 100 & $373(r)$ \\
\hline
\end{tabular}




\begin{tabular}{|c|c|c|c|}
\hline 1 & 2 & 3 & 4 \\
\hline 67 & $\begin{array}{l}\text { A. brasilense DQ438999 } \\
\text { Azospirillum sp. 7C AF411852 } \\
\text { A. brasilense AY324110 } \\
\text { A. brasilense (NCIMB 11860) Z29617 }\end{array}$ & 100 & $361(\mathrm{r})$ \\
\hline $\begin{array}{l}\text { A. brasilense } \\
\text { Sp. } 7\end{array}$ & $\begin{array}{l}\text { A. brasilense DQ438999 } \\
\text { Azospirillum sp. 7C AF411852 } \\
\text { A. brasilense AY324110 } \\
\text { A. brasilense (NCIMB 11860) Z29617 }\end{array}$ & 100 & $366(r)$ \\
\hline $\begin{array}{l}\text { A. lipoferum } \\
59 \mathrm{~b}\end{array}$ & $\begin{array}{l}\text { A. lipoferum strain ICMP EF100150 } \\
\text { A. lipoferum (ncimb 11861) Z29619 }\end{array}$ & 100 & $355(\mathrm{r})$ \\
\hline
\end{tabular}

Note: $(r)$ is a reverse primer used for amplification of $16 \mathrm{~S}$ rRNA gene at the investigated strains

Endophytic property is very useful for micro- and macrosymbionts. Plats infected with endophyts own their growth processes activated, heightened immune status and formed resistance to stress factors of environment. Localization of endophyts inside the plant tissues gives them advantages in comparison with rhizosphere microorganisms according to nutritious substances access and the absent of competition with aboriginal microflora. As well, endophyts which penetrate in inner tissues, found themselves in more comfortable conditions because of they are protected from negative influence of environment. $\mathrm{N}_{2}$-fixing endophyts, particularly Azospirillum, arouse interest because of their ecological role and possible practical application. Localization of Azospirillum bacteria in plant tissues is favourable for $\mathrm{N}_{2}$-fixing because in microzones of their localization ensured low partial oxygen pressure which is necessary for active functioning of bacterial nitrogenase and contains accessible material for this process.

Besides, the close interaction realizes between micro- and macropartner which contributes to exchange with signal molecules and metabolites. Particularly, $\mathrm{N}_{2}$ and phytohormones come in into plants without any loss.

However there are not enough understood and investigated the questions of bacteria penetrating into plant tissues. It considers that Azospirillum bacteria don't have enough pectolytic and proteolytic activity for that [2]. At the same time during thoroughly checked experimental conditions it was achieved that under the influence of host-plant the incensement of pectolytic activity became 7-8 times more 
and the incensement of proteolytic activity became 10-11 times more. According to fuller information some mycorrhizal fungi can favour Azospirillum bacteria to penerate into plants [3].

At the Institute of Agriculture Microbiology UAAS the strain of soil ascomycete Chaetomium cochliodes Palliser 3250, which manifests high antagonistic activity against culture plants root rot agents was singled out. We revealed that foil fungus C. cochliodes Palliser 3250 actively colonizes the root system of spring wheat forming carposomes on the root surface, penetrating into the root hairs and rhizoderma cells. At the same time the level of micro- and macroelements absorption gets higher, rises up the maintenance of photosynthetic pigments, proves the growth and development of plants. Thus, C. cochliodes 3250 is able to form endophytic association with spring wheat roots.

For investigation the ability of $C$. cochliodes 3250 to further to penetrate in hystosphere of spring wheat of Azospirillum bacteria in vegetative experimtnt we examined the quantity dynamics of mutant introduced in spring wheat root system together with $C$. cochliodes 3250 (fig. 2.)

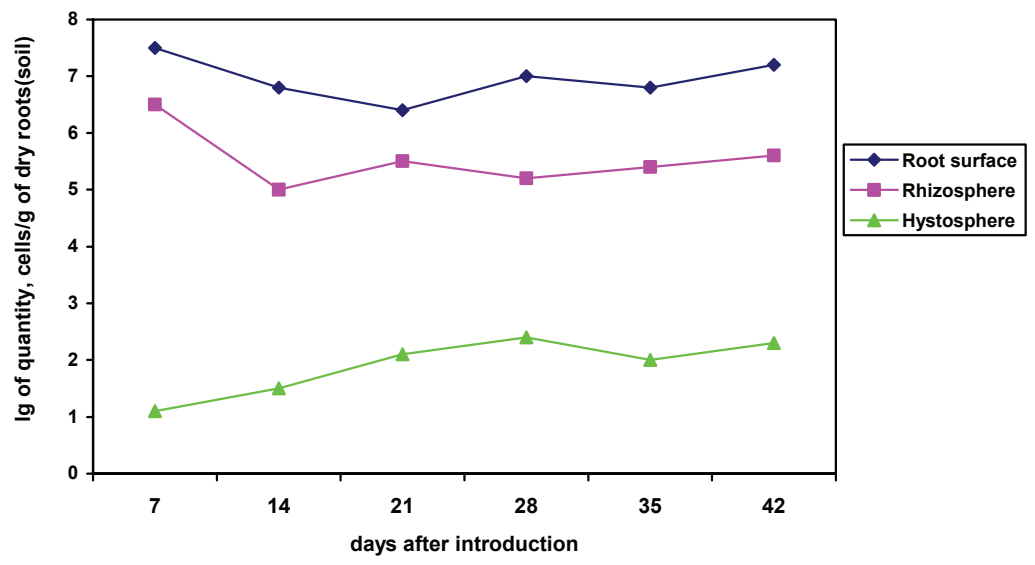

Fig. 2. Colonization of spring wheat root sphere with Azospirillum sp str

The obtained results testify that in rhizosphere soil observed little lowering and further stabilization of introduced mutant quantity on the level of 1,6-4,0 Ч $10^{5}$ bacterial cells in $1 \mathrm{~g}$ of soil. C. cochliodes 3250 was conductive to increasing the quantity of Azospirillum cells up to 3,66,4 บ $10^{6}$. We explain such fact on the basic of high antagonistic activity of $C$. cochliodes 3250 according to phytopathogenic fungi which can 38 
provoke root rots, and as we revealed earlier, during its introduction in chernozem and podzol soils takes place considerable limitation of phytopathogenic fungi from Fusarium genus. Limiting the development of phytopathogenic fungi $C$. cochliodes 3250 furthers to settling down of Azospirillum bacteria in rhizospheric soil. It is necessary to take into account the fact that for Azospirillum cells development the most favourable are the microaerobic conditions which can be made by C. cochliodes 3250 during lowering $\mathrm{O}_{2}$ containing in $\mathrm{N}_{2}$-fixing zone.

The results reveal that on the surface of spring wheat roots Azospirillum bacteria settled down more actively and their quantity was on one order more than in rhizospheric soil. The influence of C. cochliodes 3250 in this case was less aloud.

The quantity of Azospirillum bacteria in spring wheat inner tissues was greatly less and amounted 1,0-2,5 $\times 10^{2}$ bacterial cells in $1 \mathrm{~g}$ of roots. Under the influence of C. cochliodes 3250 the ability of Azospirillum bacteria to penetrate into the roots became much more (on 3-4 order) and in hystosphere of spring wheat counted 4,0 $\times 10^{5}-2,5 \times 10^{6}$ bacterial cells in $1 \mathrm{~g}$ of roots (table 2 ).

Table 2. Colonization of different spring wheat root spheres with $A$. brasilense $102^{\text {str }}$ (vegetative experiment)

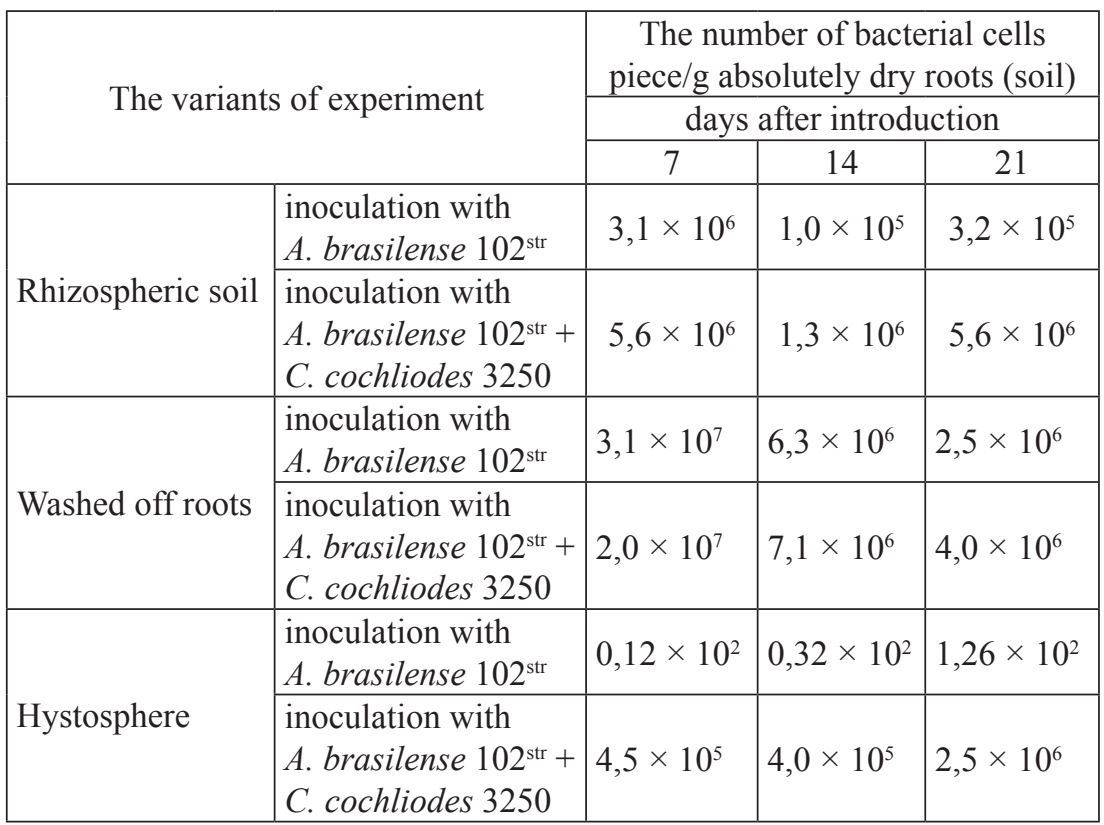


Thus it is possible to make a conclusion that forming endophyt association with spring wheat roots $C$. cochliodes 3250 furthers to settle down of Azospirillum bacteria in rhizospheric soil and hystosphere of spring wheat.

Complex inoculation of spring wheat with A. brasilense $104^{\text {str }}$ and $C$. cochliodes 3250 told upon chloroplast genesis of the culture (table 3 ). The plants during it were characterized by high maintenance of chlorophylls $a$ and $b$ in leafs.

Table 3. The influence of spring wheat inoculation with microorganisms on chlorophyll $a$ and $b$ maintenance in leafs of

plants (vegetative experiment)

\begin{tabular}{|c|c|c|c|}
\hline \multirow[t]{2}{*}{ The variants of experiment } & \multicolumn{3}{|c|}{$\begin{array}{l}\text { Chlorophyll concentration, } \mathrm{mg} / 100 \mathrm{~g} \\
\text { of leafs }\end{array}$} \\
\hline & $a$ & $b$ & $a+b$ \\
\hline Without inoculation (control) & 42,56 & 13,86 & 56,42 \\
\hline $\begin{array}{l}\text { Inoculation with } \\
\text { A. brasilense } 104^{\text {str }}\end{array}$ & 52,87 & 17,95 & 70,85 \\
\hline $\begin{array}{l}\text { Inoculation of seeds with } \\
\text { A. brasilense } 104^{\mathrm{str}}+ \\
\text { C. cochliodes } 3250\end{array}$ & 68,85 & 23,84 & 92,69 \\
\hline The less essential difference ${ }_{05}$ & 0,80 & 1,23 & \\
\hline
\end{tabular}

Thus, the strain of $A$. brasilense 104 during its introduction in root system of spring wheat actively colonizes rhizospheric soil, root surface and is able to penetrate in inner plant tissues. The soil ascomucete C. cochliodes 3250 furthers for better settling down of Azospirillum cells in spring wheat root zone especially in plants hystosphere which has an effect on increasing of chlorophyll $a$ and $b$ in the leafs of the culture.

1. Caceras S.A.R. Improved medium for isolation of Azospirillum spp. /Caceras S.A.R. //Appl. Environ. Microbiol. - 1982. - Vol. 44, № 4. - P. 990991.

2. Okon Y. Development and function of Azospirillum- inoculated roots /Okon Y., Kapulnik Y. //Plant and Soil. - 1986. - Vol. 90, N 1. - P. 3-16.

3. Paula M.A. Synergistic effects of vesicular-arbuscular mycorrhizal fungi and diazotrophic bacteria on nutrition and growth of sweet potato (Ipomoea batatas) /Paula M.A., Urquiaga S., Siqueira J.O., Dodereiner J. //Biol. Fertil. Soils. - 1992. - Vol. 14. - P. 61-66.

4. Tarrand J.J. A taxonomic study of the Spirillum lipoferum group, 
with descriptions of a new genus, Azospirillum gen. nov. and two species, Azospirillum lipoferum (Beijerinck) comb. nov. and Azospirillum brasilense sp. nov. /Tarrand J.J., Krieg N.R., Dobereiner J. //Can. J. Microbiol. - 1978. - Vol. 24. - P. 967-980.

5. Гродзинский А.М. Краткий справочник по физиологии растений /А.М. Гродзинский, Д.М. Гродзинский. - К.: Наук. думка, 1973. - 567 с.

6. Методы экспериментальной микологии: Справочник /Под ред. В.И. Билай. - К.: Наук. думка, 1982. - 549 с.

7. Мирчинк Т.Г. Почвенная микология /Мирчинк Т.Г. - М.: Изд. МГУ, 1976. - 206 с.

8. Определитель бактерий Берджи /Под ред. Дж. Хоулта, Н. Крига, П. Снита, Дж. Стейнли, С. Уилльямса: Пер. с англ. под ред. Г.А. Заварзина. - М.: Мир, 1997. - 800 с.

\section{ПРИЖИВАЕМОСТЬ АЗОСПИРИЛЛ В КОРНЕВОЙ ЗОНЕ ЯРОВОЙ ПШЕНИЦЫ ПОД ВЛИЯНИЕМ ПОЧВЕННОГО ГРИБА СНAETOMIUM COCHLIODES 3250}

\section{Копылов Е.П.}

Институт сельскохозяйственной микробиологии УААН, г. Чернигов

Из ризосферной почвы, отмытых корней и гистосферы яровой пшениць выделены активные итаммы бактерий рода Azospirillum, способнье к фиксации атмосферного азота. Изучение фенотипических признаков и проведение молекулярно-генетического анализа позволило отнести их $к$ Azospirillum brasilense. Показано, что штамм A. brasilense 104 при интродукции в корневую систему яровой пшенииь активно колонизирует ризосферную почву, поверхность корней и способен проникать во внутренние ткани растений. Почвенный сумчатый гриб Chaetomium cochliodes 3250 способствует лучшей приживаемости азоспирилл в корневой зоне яровой пиеницы, особенно в гистосфере растений, что отражается на увеличении содержания хлорофиллов $а$ u $b$ в листьях культуры.

Ключевые слова: Azospirillum brasilense, диазотрофы, яровая пшеница, эндофиты, хлорофилл, Chaetomium cochliodes 3250. 


\section{ПРИЖИВАНІСТЬ АЗОСПІРИЛ У КОРЕНЕВІЙ ЗОНІ ПШЕНИЦІ ЯРОЇ ПІД ВПЛИВОМ ГРУНТОВОГО ГРИБА СНAETOMIUM COCHLIODES 3250 \\ Копилов Є.П.}

Інститут сільськогосподарської мікробіології УААН, м. Чернігів

Із ризосферного грунту, відмитих кооренів та гістосфери пшениці ярої виділені активні штами бактерій роду Azospirillum, здатні фіксувати атмосферний азот. Вивчення ознак фенотипу $i$ проведення молекулярно-генетичного аналізу дозволило віднести ïx до Azospirillum brasilense. Показано, щзо штам A. brasilense 104 при інтродукиії в кореневу систему пшениці ярої активно колонізує ризосферний трунт, поверхню коренів $i$ здатен проникати $y$ внутрішні тканини рослин. Грунтовий сумчатий гриб C. cochliodes 3250 сприяе кращій приживаності азоспірил в кореневій зоні пшениці ярої, особливо у гістосфері рослин, що позначається на збільшенні вмісту хлорофілів а і в в листках культури.

Ключові слова: Azospirillum brasilense, діазотрофи, пшениия яра, ендофіти, хлорофіл, Chaetomium cochliodes 3250. 